Bangladesh J. Bot. 48(4): 957-965, 2019 (December)

\title{
DEVELOPMENT AND EVALUATION OF FLAVOURED LADOO FROM DIFFERENT CULTIVARS OF AONLA
}

\author{
Nitish Pandita and Neeraj Gupta* \\ Division of Food Science and Technology, SKUAST-Jammu, Chatha J\&K-180 009, India
}

Keywords: Aonla cultivars, Refined sugar, Raw sugar, Quality attributes

\begin{abstract}
Small balls of 'Ladoos' were made by using blended aonla fruit of three cultivars with refined and raw sugar, ginger and cardamom flavours. The prepared 'Ladoos' were stored in pet boxes for three months to ascertain the changes in chemical, sensory and microbiological characteristics. An increasing trend was observed in TSS, reducing and total sugars but decreasing trend in titratable acidity, tannin and ash during three months of storage. The highest microbial count of $1.45 \times 10^{6} \mathrm{cfu} / \mathrm{g}$ was recorded in treatment $\mathrm{T}_{12}(\mathrm{desi}+$ ginger + raw sugar) and the lowest of $0.41 \times 10^{6} \mathrm{cfu} / \mathrm{g}$ in $\mathrm{T}_{9}(\mathrm{NA}-7+$ cardamom + raw sugar) at the end of storage. On the basis of overall acceptability, $\mathrm{T}_{3}$ (NA-7 + cardamom + refined sugar) was found to be the best treatment. The storability study revealed that 'Ladoos' prepared from cultivar NA-7 have good-shelf life and can be kept for more than 90 days without affecting the quality attributes.
\end{abstract}

\section{Introduction}

Aonla (Emblica officinalis Gaertn), which is also known as the Indian gooseberry, is a smallsized, minor sub-tropical fruit and grows widely along the hill sides and sub-mountainous areas of North India. It can be grown successfully in dry and neglected regions owing to its hardy nature, suitability to various kinds of wasteland. The major aonla producing states in India are Rajasthan, Uttar Pradesh, Gujarat, Tamil Nadu, Maharashtra, Andhra Pradesh, Karnataka and Bihar. Total area and production under aonla cultivation in India is around 108 thousand hectares and 1266 thousand tonnes, respectively (Anon. 2013). As per the statistical figures obtained from J\&K department of horticulture, the present area under aonla cultivation is about 1632 hectares with an annual production of 1496.8 metric tonnes (Anon. 2013a).

The fruit is used as an antiscorbic, diuretic and laxative (Singh and Pathak 1987), hence used for treating common cold, gastric troubles, acidity and scurvy (Tandon et al. 2003), dysentery, bronchitis, diabetes, diarrhoea, jaundice and dyspepsia (Bhosale et al. 2000) and cough, asthma, headache, ophthalmic disorders, colic, flatulence, skin diseases, leprosy and grayness of hair etc. (Shekhawat et al. 2014). Fruit is extensively used in the preparation of Ayurvedic and Unani medicines like Chyavanprash, which promotes health and longevity (Rajkumar et al. 2001). It contains 500 - $1500 \mathrm{mg}$ of ascorbic acid per $100 \mathrm{~g}$ of pulp. Due to acidic and astringent taste, the fresh consumption of aonla fruit is less and hence various products like preserve, segments-insyrup, candy, squash, juice, powder, etc are prepared from the fruit. Multi grain ladoo is galactogouge and nutritionally rich product. It is prepared with varied kinds of flour, nuts, functional food "Dink" and Ghee. The product provides good amounts of biological proteins, functional property, vitamins, minerals and adequate fiber and has a good satiety value (Naidu et al. 2013). Different types of ladoos are traditionally prepared from flours, coconut, turmeric etc., but the work on ladoo from various types of fruits is very less. Moreover, there is always a demand from the consumers all over the world for new products, which should be nutritious and delicately flavoured. Hence, attention has been focused on development of flavoured ladoo.

*Author for correspondence: <neeruguptapht@gmail.com>. 


\section{Materials and Methods}

Fully matured fruits of aonla (Emblica officinalis Gaertn) ware procured from the Rainfed Research Sub-Station for Subtropical Fruits (RRSS), SKUAST-J, Raya, Samba (J\&K) and were taken to Food Processing and Training Centre of Division of Food Science and Technology, SKUAST-J, Udheywalla, Jammu for further processing during the year $2014-15$. The defective and injured fruits were sorted out, discarded and the good selected fruits were thoroughly washed with fresh water and steamed. Stones were removed and pulp segments crushed into paste. Fine sugar/raw sugar was added to paste and it was cooked till final consistency of $70{ }^{0}$ Brix was obtained. After adding flavor of cardamom and ginger, the mass was cooled and ladoos were made and packed into PET boxes for further observations (Figs 1, 2, 3). The total number of treatment combinations was 12 with three replications and the experiment was designed complete randomly in factorial. The data obtained was subjected to statistical analysis for analysis of variance using standard methods (Gomez and Gomez 1984). The chemical analysis of fruit product (ladoo) was conducted for TSS, reducing sugars, total sugars and tannin (Ranganna 1986), titratable acidity (AOAC 1994) and ash content (AOAC 2000). The product was organoleptically evaluated by departmental semi-trained panel members using 9 point hedonic rating.

\section{Results and Discussion}

After one month of storage, treatment $\mathrm{T}_{3}$ (NA-7 + cardamom + refined sugar) was found to have highest total soluble solids (TSS) of $71.40^{\circ} \mathrm{Brix}$ followed by treatment $\mathrm{T}_{4}(\mathrm{NA}-7+$ ginger + refined sugar) and treatment $\mathrm{T}_{1}$ (Banarsi + cardamom + refined sugar) having values as 71.36 and $71.35^{0}$ Brix, respectively. After three months of storage treatment $\mathrm{T}_{3}$ (NA-7 + cardamom + refined sugar) registered the highest values of TSS to the tune of $73.40{ }^{\circ}$ Brix whereas treatment $\mathrm{T}_{12}$ (desi + ginger + raw sugar) showed the lowest TSS of $71.62{ }^{0}$ Brix. During entire storage period, the TSS increased significantly from 70.06 to $72.37{ }^{\circ}$ Brix. The effect of treatment, storage and its interaction was statistically significant (Table 1). The increase in total soluble solids might be due to partial hydrolysis of polysaccharides like cellulose, starch and pectic substances into simple substance or due to solidification of pulp constituents during storage. Similar results were reported by Pathak (1988) in aonla jam, Kumar (1990) in papaya jam, Kannan and Thirumaran (2001) in jamun jam, Badal et al. (2006) in strawberry, banana and mulberry blended jam and Prasad and Mali (2006) in ber jam.

The titratable acidity in aonla ladoos decreased during three months of storage. Initially, the highest titratable acidity of $0.28 \%$ was recorded in treatment $\mathrm{T}_{12}$ (desi + ginger + raw sugar) followed by treatment $\mathrm{T}_{11}(\mathrm{desi}+$ cardamom + raw sugar). After three months of storage, the highest and lowest titratable acidity content were recorded in treatments $\mathrm{T}_{12}(\mathrm{desi}+$ ginger + raw sugar) and $\mathrm{T}_{3}$ (NA-7 + cardamom + refined sugar) as 0.22 and $0.10 \%$, respectively (Table 1 ).

Non-significant differences were found between treatment and storage interaction while as the effect of treatment and storage was significant. The decrease in acidity might be attributed to the bio-conversion of acid to sugars resulting in lowering of acidity during storage and the decrease might also be due to chemical interaction between organic constituents of the fruit induced by the action of enzymes and storage temperature. Similar findings were reported by Kohale and Rokhade (2012) in sapota 'burfi' and Priya and Khatkar (2013) in aonla preserve.

A significant increase in reducing sugar content was observed during the storage period of aonla ladoos. The highest reducing sugar content of $35.2 \%$ was recorded in $\mathrm{T}_{3}$ (NA-7 + cardamom + refined sugar) followed by $34.2 \%$ in treatment $\mathrm{T}_{4}$ (NA-7 + ginger + refined sugar) and lowest of $25.3 \%$ in $\mathrm{T}_{12}$ (desi + ginger + raw sugar) after one month of storage (Table 1). After three months of storage, treatment $\mathrm{T}_{3}$ (NA-7 + cardamom + refined sugar) was found to have highest value of 
$39.1 \%$ followed by treatment $\mathrm{T}_{4}$ (NA-7 + ginger + refined sugar) and lowest value of $29.1 \%$ was recorded in $\mathrm{T}_{12}$ (desi + ginger + raw sugar). On the basis of overall mean values, reducing sugars of $36.2 \%$ was highest in $\mathrm{T}_{3}$ (NA-7 + cardamom + refined sugar) and lowest of $26.18 \%$ in $\mathrm{T}_{12}$ (desi + ginger + raw sugar). Increase in reducing sugars during storage might be due to hydrolysis of polysaccharides and inversion of non reducing sugars to reducing sugars. The present findings are in conformity with the results reported by Kannan and Thirumaran (2001) in jamun jam, Sogi and Singh (2001) in kinnow jam and Shakir et al. (2009) in apple and pear mixed jam. Vidhya and Narain (2010) also reported the same trend in wood apple jam.

At two months of storage, the highest amount of total sugar content of $47.60 \%$ was recorded in treatment $\mathrm{T}_{3}$ (NA-7 + cardamom + refined sugar) and the lowest of $38.20 \%$ in $\mathrm{T}_{12}$ (desi + ginger + raw sugar). As the storage period advanced, total sugar content increased and maximum total sugar content of $49.35 \%$ was recorded in treatment $\mathrm{T}_{3}$ (NA-7 + cardamom + refined sugar) and minimum of $40.50 \%$ was recorded in treatment $\mathrm{T}_{12}$ (desi + ginger + raw sugar) after 3 months of storage. Mean value of total sugars increased from 38.80 to $44.60 \%$ during three months of storage. However, interaction between treatments and storage period was found to be significant (Table 2). The increase in total sugar content during storage could be attributed to gradual inversion of non-reducing sugars (Jain et al. 1988) and also to the breakdown of polysaccharides into simple sugars (Sogi and Singh 2001) in kinnow jam. Similar results have also been reported by Vidhya and Narain (2010) in wood apple jam.

Tannin content in the flavoured aonla ladoo showed significant difference among cultivars, treatments and storage durations. Among the various treatment combinations, $\mathrm{T}_{12}(\mathrm{desi}+$ ginger + raw sugar) showed the highest tannin content of $0.68 \mathrm{mg} / 100 \mathrm{~g}$ and lowest tannin content of 0.56 $\mathrm{mg} / 100 \mathrm{~g}$ was recorded in $\mathrm{T}_{3}$ (NA-7 + cardamom + refined sugar) after one month of storage. After three months of storage treatment $\mathrm{T}_{12}(\mathrm{desi}+$ ginger + raw sugar) recorded maximum and treatment $\mathrm{T}_{3}$ (NA-7 + cardamom + refined sugar) recorded the minimum tannin content of 0.65 and $0.52 \mathrm{mg} / 100 \mathrm{~g}$, respectively. Maximum overall mean tannin content of $0.68 \mathrm{mg} / 100 \mathrm{~g}$ was recorded in treatment $\mathrm{T}_{12}$ (desi + ginger + raw sugar) and the lowest $0.55 \mathrm{mg} / 100 \mathrm{~g}$ was in $\mathrm{T}_{3}$ (NA$7+$ cardamom + refined sugar). Significant decrease in tannin content was observed with the progress in storage period in all the treatments under study. The mean values of storage period showed a decreasing trend from the initial levels of 0.64 to $0.59 \mathrm{mg} / 100 \mathrm{~g}$ after three months of storage (Table 2). Nayak et al. (2011 and 2012) noticed a decrease in tannin content in aonla segments during storage period at room temperature. The decrease in tannins during storage might be due to the formation of precipitates with organic constituent.

A significant decrease in ash content was observed during storage from 0.25 to 0.16 per cent. At two months of storage, the highest ash contents of $0.28 \%$ was recorded in treatment $\mathrm{T}_{3}$ (NA-7+ cardamom + refined sugar) and the lowest was $(0.12 \%)$ in treatment $\mathrm{T}_{12}(\mathrm{desi}+$ ginger + raw sugar). After three months of storage the maximum ash content of $0.26 \%$ was observed by treatment $\mathrm{T}_{3}$ (NA-7 + cardamom + refined sugar) followed by $\mathrm{T}_{4}$ (NA-7 + ginger + refined sugar) and it was lowest in $\mathrm{T}_{12}$ (desi + ginger + raw sugar). However the interaction between the treatment and storage was non-significant. Due to increase in moisture content, ash content of aonla ladoo decreased with the increase in storage period (Table 2). These results are in accordance with the findings of Khan et al. (2014). Presence of high amount of ash is the indication of the presence of higher amounts of some of the essential elements such as K, Na, P etc. (Ting and Rouseff 1986).

All the samples were found to be free from microbial count up to two months of storage (Table $3)$. However, after three months of storage, the highest microbial count of $1.45\left(\times 10^{6} \mathrm{cfu} / \mathrm{g}\right)$ was observed in treatment $\mathrm{T}_{12}$ (desi + ginger + raw sugar) and lowest of $0.41\left(\times 10^{6} \mathrm{cfu} / \mathrm{g}\right)$ was in 


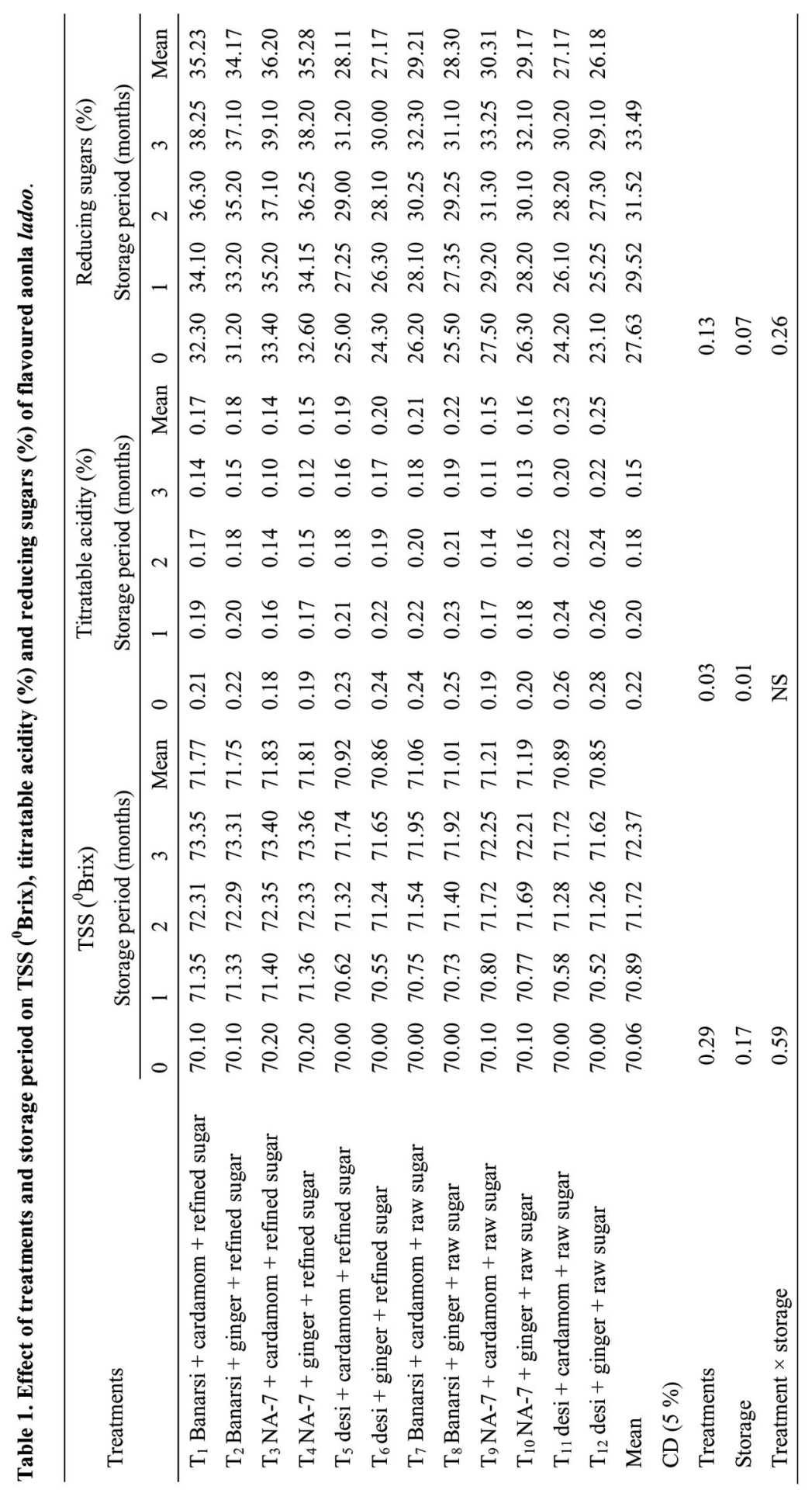




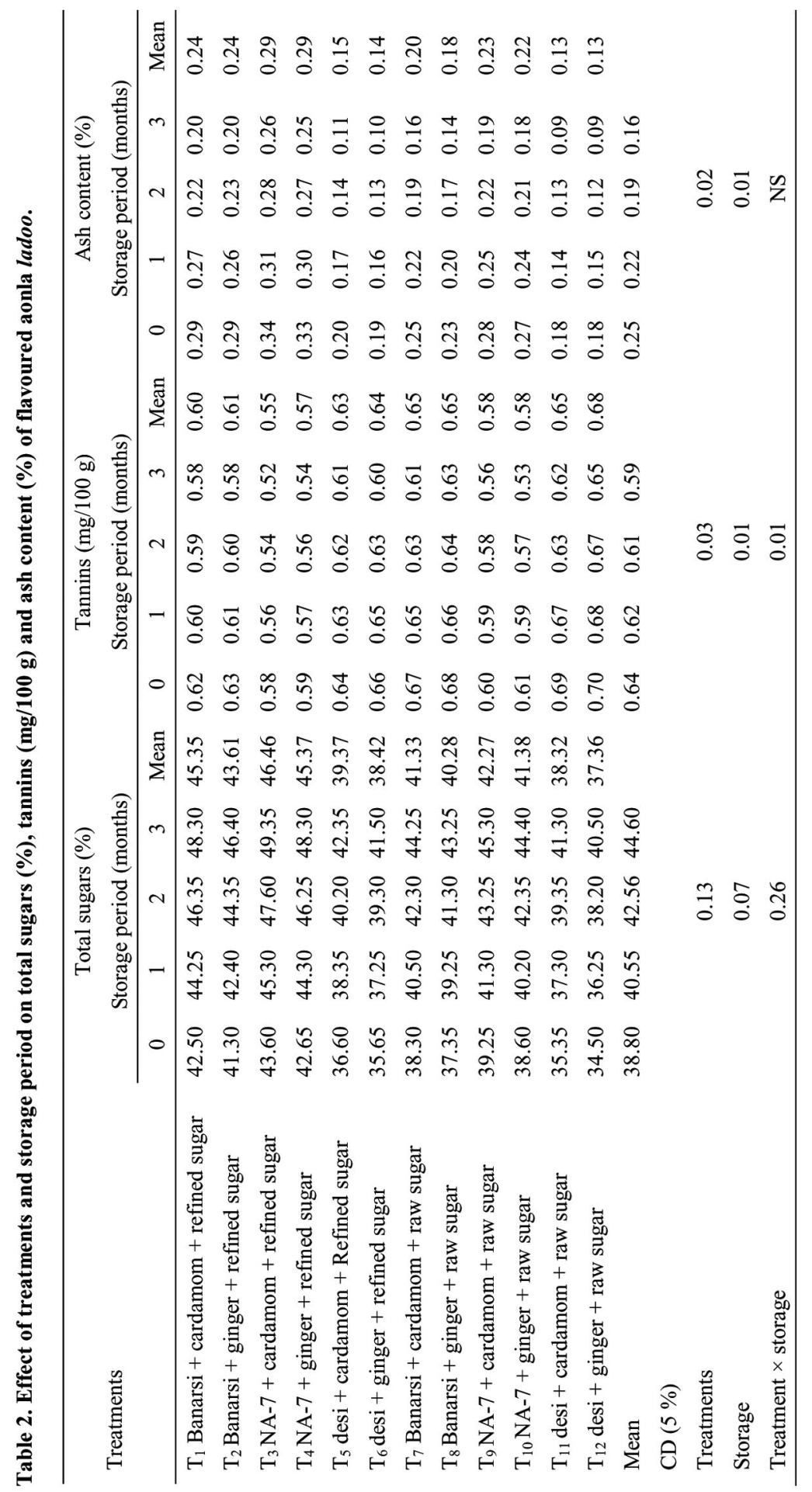




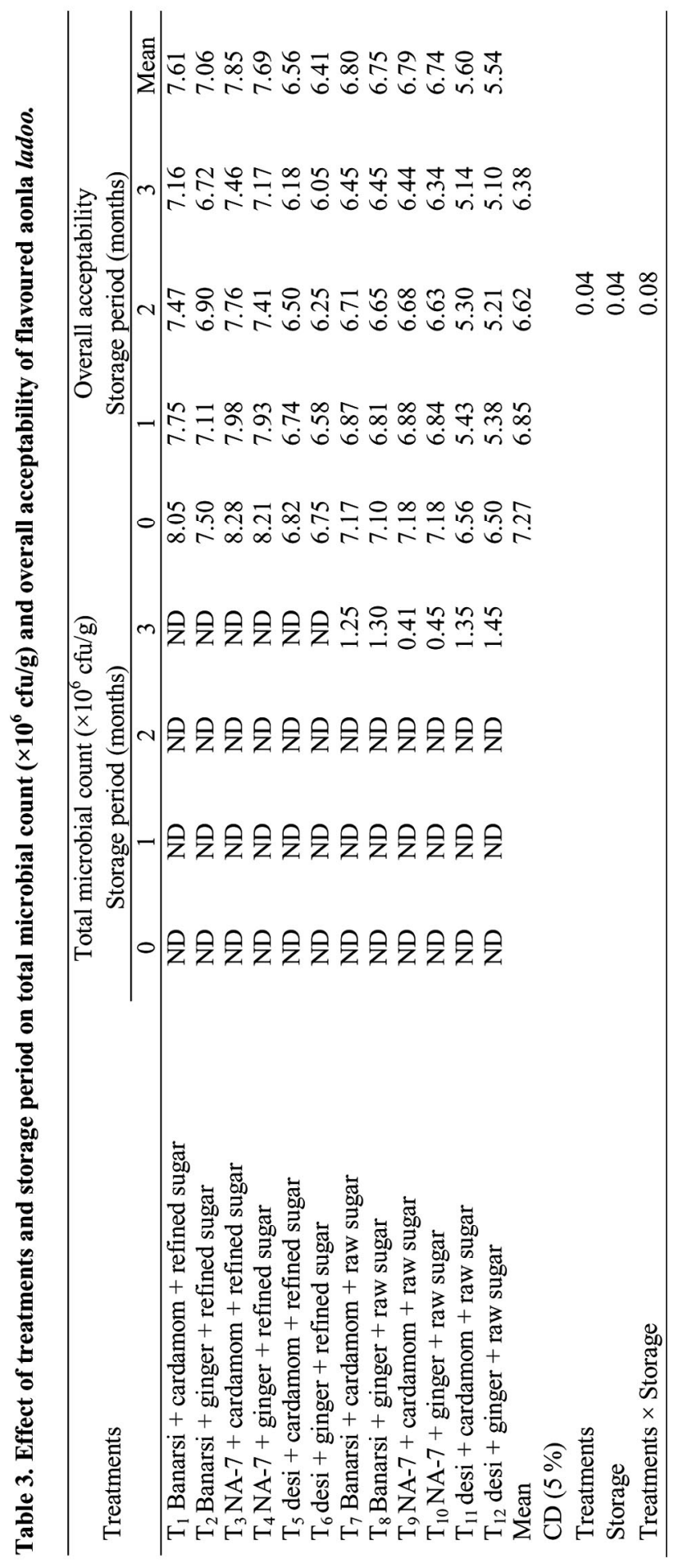


treatment $\mathrm{T}_{9}$ (NA-7 + cardamom + raw sugar). Gargi et al. (1995) did not observe any microbial growth in the product sealed properly in glass jar after one month of storage. An acceptable count of microbes were also observed in wood apple jam and fruit bar at the end of storage period (Vidhya and Narain 2010).

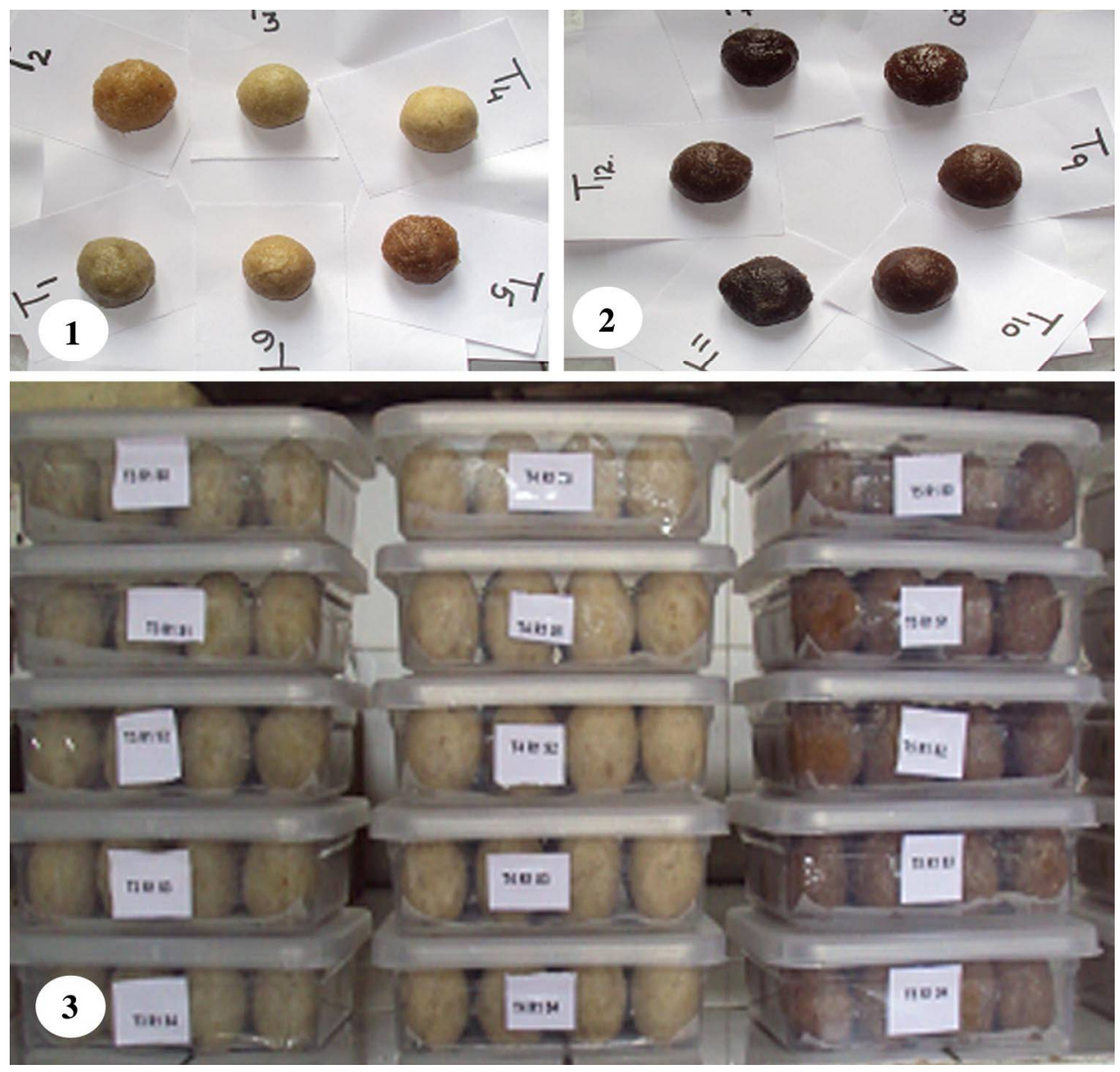

Figs 1-3: 1. Flavoured aonla ladoo developed from refined sugar. 2. Flavoured aonla ladoo developed from raw sugar and 3. Aonla ladoo developed from different treatment combinations packed in PET boxes.

The overall acceptability score of flavoured aonla ladoo decreased over a period of three months (Table 3). After three months of storage; treatment $\mathrm{T}_{3}$ (NA-7 + cardamom + refined sugar) registered the highest score of 7.46 which was closely followed by treatment $\mathrm{T}_{4}(\mathrm{NA}-7+$ ginger + refined sugar) and $\mathrm{T}_{1}$ (Banarsi + cardamom + refined sugar) having scores as 7.17 and 7.16, respectively; however these two treatments $\left(T_{4}\right.$ and $\left.T_{1}\right)$ were statistically at par and the lowest score of 5.10 was assigned to $\mathrm{T}_{12}$ (desi + ginger + raw sugar). The mean storage score for overall acceptability attributes decreased from 7.27 to 6.38 during three months of storage. The decrease in overall acceptability scores in product may be due to increase in non-enzymatic browning to some extent, change in chemical composition of the product and loss of colour and flavour during 
storage period of 3 months. Similar findings was reported by Nayak et al. (2011) in aonla segments in syrup, Singh et al. (2012) in aonla supari, Priya and Khatkar (2013) in aonla preserve and Khan et al. (2014) in guava bar.

\section{References}

Anonymous 2013. Area and production of horticultural crops. Department of Agriculture and co-operation (Horticulture Division), Govt. of India.

Anonymous 2013 a. Annual area and production report. Department of Horticulture, Gole pulli, Talab Tillo, Jammu, Jammu and Kashmir.

AOAC 1994. Official methods of analysis. Association of Official Agricultural Chemists, Inc. Washington, D.C.

AOAC 2000. Official methods of analysis international. 17th edition. AOAC international Maryland. U.S.A.

Badal J, Goyal RK and Godara AK 2006. Studies on storage of mixed jam from strawberry, banana and mulberry. Har. J. Hort. Sci. 35(3-4): 239-241.

Bhosale VI, Kutte LS and Kadam SS 2000. Studies on preparation of ready to serve beverage from aonla: mango juice blend. Bever. and Food World 27(2): 24-27.

Gargi N, Tandon DK and Kalara SK 1995. Determination of microbial load during various steps of mango processing for pulp. Bever. and Food World 22(3): 14-15.

Gomez KA and Gomez AA 1984. Statistical procedures for Agricultural Research $\left(2^{\text {nd }}\right.$ Edition). A WileyInterscience publication, John Wiley and Sons, New York.

Jain SP, Tripathi VK, Ram HB and Singh S 1988. Varietal suitability of litchi for squash making. Ind. Food Packer 42(1): 29-33.

Kannan S and Thirumaran AS 2001. Studies on storage life of jamun products. Ind. Food Packer 55(6): 12527.

Khan M, Ayub M, Durrani Y, Wahab S, Muhammad A, Ali SA, Shakoor A, Arsalan and Rehman Z 2014. Effect of sucrose and stabilizer on the overall quality of guava bar. World J. Phar. and Pharmac Sci. 3(5): 130-46.

Kohale V and Rokhade AK 2012. Studies on preparation of sapota burfi. Bioinfolet 9(3): 336-40.

Kumar S 1990. Studies on post harvest technology of papaya (Carica papaya L.) fruits. PhD Thesis, Narendra Dev University of Agricultural Sciences and Technology, Faizabad, U.P, India.

Naidu GB, Shirke JK and Shekhar A 2013. A study of a galactogouge and protein rich multi grain ladoo. Int. J. Food and Nutr Sci. 2(4): 91-94.

Nayak P, Bhatt DK, Shukla DK and Tandon DK 2011 Evaluation of aonla (Emblica officinalis Gaertn) segments-in-syrup prepared from stored fruits. Res J. Agric. Sci. 43(2): 252-57.

Nayak P, Tandon DK and Bhatt DK 2012. Study on changes of nutritional and organoleptic quality of flavoured candy prepared from aonla (Emblica officinalis Gaertn). Int. J. Nutr. and Metabol. 4(7): 100-06.

Pathak S 1998. Post harvest technology of aonla (Emblica officinalis Gaertn) fruits. Ind. Food Packer 49(4): 43-46.

Prasad RN and Mali PC 2006. Changes in physico-chemical characteristics of ber jam during storage. Ind. J. Hort. 63 (1): 86-87.

Priya MD and Khatkar BS 2013. Effect of processing methods on keeping quality of aonla (Emblica officinalis Gaertn.) preserve. Int. Food Res J. 20(2): 617-22.

Rajkumar N V, Therese M and Kuttan R 2001. Emblica officinalis. Fruits afford protection against experimental gastric ulcers in rats. Pharma Biol. 39: 375-80.

Ranganna S 1986. Handbook of Analysis and Quality Control for Fruit and Vegetable Products. Tata McGraw-Hill Publishing Co. Ltd. New Delhi. 
Shakir I, Imtiaz H, Zeb A and Durrani Y 2009. Sensory evaluation and microbial analysis of apple and pear mixed fruit jam prepared from varieties grown in Azad Jammu and Kashmir. World J. Dairy and Food Sci. 4(2): 201-04.

Shekhawat S, Rathore N S and Kaushik R A 2014. Advances in processing and product development of aonla (Emblica officinalis) in Indian context - A Review. Int. J. Food and Nut Sci. 3(6): 242-247.

Singh IS and Pathak RK 1987. Evaluation of aonla (Emblica officinalis Gaertn) varieties for processing. Acta Horti. 208: 173-77.

Singh J, Koul RK, Bhat A, Sood M and Dogra J 2012. Comparative studies on compositional changes in aonla (Emblica officinalis) supari during storage. Ann. Food Sci. and Technol. 13(1): 19-24.

Sogi D S and Singh S 2001. Studies on bitterness development in Kinnow juice, ready-to-serve, beverages, squash, jam and candy. J. Food Sci Technol. 38: 433-38.

Tandon DK, Yadav RC, Sood S, Kumar S and Dikshit A 2003. Effect of blanching and lye peeling on the quality of aonla candy. Ind. Food Packer 57(6): 147-52.

Ting SV and Rouseff RL 1986. Citrus fruits and their products, Analysis and Technology. Marcel Dekker, Inc. New York.

Vidhya R and Narain A 2010. Development of preserved products (jam and fruit bar) from under exploited wood apple 'Limonia acidissima' fruits. African J. Food and Technol. 1(2): 51-57.

(Manuscript received on 22 March, 2018; revised on 19 March, 2019) 